Law enforcement agencies are in a position to be of great service to battered women, yet they have recently been criticized for the manner of their response. This survey of police officers, battered women, and advocates for battered women was conducted to shed light on the controversy over the police response. The results show that officers generally viewed marital violence as criminal and unacceptable, yet very few saw arrest as the best solution. In contrast, the majority of victims wanted arrest used, often to force the offender to get help in addition to being punished.Victim-blaming by officers was related to traditional views of women's roles. Somewhat divergent views and negative stereotyping seemed to characterize the police-advocate relationship. Recommendations for improving police-advocate dialogue and police training are given.

\title{
Attitudes About Woman Abuse Among Police Officers, Victims, and Victim Advocates
}

\author{
DANIEL G. SAUNDERS \\ University of Wisconsin-Madison \\ PATRICIA B. SIZE \\ Mendota Mental Health Institute, Wisconsin
}

Abuse of women by their intimate partners has surfaced as a major social problem, more serious and widespread than anyone anticipated 10 years ago (Gaquin, 1977; Straus, Gelles, \& Steinmetz, 1980). Compounding the plight of battered women are the responses of many social institutions to which these women turn for help. There are numerous accounts of apathetic and even hostile responses from those in a position to help (Bowker, 1983; Martin, 1976).

The response of law enforcement agencies has not escaped criticism and, indeed, is perhaps the most severely criticized (Field \& Field,

Authors' Note: This study was supported in part by grant 77-0620SC29636 from the Wisconsin Council on Criminal Justice and grants MH-1516106 and MH-1713901 from the National Institute of Mental Health. We are grateful to Larry Baron, Diane Coleman, David Finkelhor, Gerald Hotaling, and Jay Meehan for their helpful comments on earlier versions of this manuscript. We especially want to thank Helen Sklar for her contributions to the early stages of the project.

JOURNAL OF INTERPERSONAL VIOLENCE, Vol. 1 No. 1, March 1986 25-42 ๑) 1986 Sage Publications, Inc. 
1973; Fields, 1978; Gregory, 1976; Reed, Fischer, Kantor, \& Karales, 1983; Truninger, 1971; U.S. Commission, 1982). It is important to understand the nature of these criticisms in order to attempt to improve the law enforcement response. This understanding is especially important because law enforcement agencies are often the first or only place the battered woman calls for help and officers are in an excellent position to respond immediately with a variety of services and law enforcement actions.

One criticism of law enforcement agencies is that their training programs usually stress the use of family crisis intervention techniques, which often recommend arrest as a last resort and present wife abuse as a nonserious matter arising from marital conflict (Fields, 1978). Helping couples resolve conflict or urging them to separate for the night does not provide adequate protection to the victim because the abuser can return and resume the abuse after the police leave (Martin, 1977; Reed et al., 1983). Mediation by Officers has not been conclusively shown to be effective in reducing family assaults (Wylie, Basinger, Heinecke, \& Rueckert, 1976) and in one small sample study was less effective than arrest (Sherman \& Berke, 1984). In trying to equalize responsibility for family problems, mediation may give the impression that assaultive behavior is justifiable (Fields, 1978). In a comparison of prosecuted cases and cases mediated by trained mediators, however, long-term follow-up did not show a difference in recidivism rates as measured by follow-up reports and arrest records (Smith, 1983).

Mediation of the family crisis intervention approach seems to stem from family therapy approaches that do not recognize male-female power differences within the family (see Libow, Raskin, \& Caust, 1982). Some applications of family systems theory presume that family members are of equal power and contribute equally to all family problems. In addition, there is experimental evidence that people generally view assaults between intimates as less serious and less in need of intervention than assaults between strangers (Shotlund \& Straw, 1976). In line with this evidence, the police tend to arrest those suspected of committing a crime against a stranger rather than an intimate (Black, 1982). Class action suits against police departments in several cities were based on the allegation that proper legal and medical aid was not given to battered women because they were married to their assailants (Woods, 1981).

Another related criticism is that officers are apathetic or hostile toward female victims because of the officers' socialization into the masculine role and the approval of the use of force (Bannon, 1975). 
Some experimental evidence shows that men, but not women, are reluctant to intervene when a man assaults a woman and that men do not hesitate as much to stop two men from fighting (Borofsky, Stollak, \& Meese, 1971). One study of police officers revealed that those who took the least amount of action in wife abuse cases were more likely to hold traditional views of women and approve more of marital violence (Saunders, 1980).

Surveys of battered women's perceptions of police response are not as negative as might be expected from reading case accounts and class action suit affidavits. In four surveys, between $20 \%$ and $47 \%$ of abused women calling the police viewed the officers' response as helpful (Carlson, 1977; Fojtik, 1977/1978; Roy, 1977; Saunders \& Size, 1980). In one study, however, the police were rated as the least helpful and most indifferent out of a group of 13 formal and informal helpers (Saunders \& Size, 1980) and the least successful of nine helpers in another (Bowker, 1983).

From the officers' viewpoint, there are several reasons to refrain from taking action. Because the cases involve close relationships, they are among the most complicated and unpredictable and are emotionally draining for many officers. Some officers therefore feel that family calls, including those involving assaults, are best served by social workers (Borkowski, Murch, \& Walker, 1983). When officers urge victims to take legal or personal action, they perceive that victims often do not follow through. Many officers feel they have wasted their time if they make an arrest and the victim or prosecutor does not want prosecution to occur (Reed et al., 1983). Good intentions may turn to frustration and victim-blaming (see Borkowski et al., 1983). Officers may conclude after a period of months or years that calls are made out of revenge or that women enjoy being abused. In addition, officers may see the use of arrest as causing violence at the scene or as harmful to the long-term welfare of the family (Bard \& Connolly, 1978). Officers are told that these are the most dangerous cases they will face, despite evidence to the contrary (U.S. Commission, 1982). There is evidence, however, that most officers believe that arrest is needed in cases involving severe injuries (Loving, 1981).

In contrast to the above perceptions, one study showed that officers' use of arrest was not associated with the extent of victim injuries and women's calls to the police were not associated with feelings of hatred and revenge but rather with the seriousness of the assault (Saunders \& Size, 1980). Also in contrast to police perceptions, domestic assault victims have been shown to cooperate with the police more than other assault victims (Oppenlander, 1982). 
The notion that abused wives enjoy their abuse has been refuted by evidence from personality studies and interviews with thousands of battered women (Price \& Armstrong, 1978; Star, Clark, Goetz, \& O'Malia, 1979). Rather than enjoying abuse, the women are often reluctant to leave or to testify against their mates because their mates threaten to harm them or because of roadblocks they encounter within the criminal justice system (Reed et al., 1983).

The various perceptions of the police response to domestic violence have received little systematic study. The present study was designed to examine police, victim, and victim advocate perspectives on woman abuse, and the police response to the problem, with the hope of making suggestions for more effective training and policy guidelines. Specifically, questions were asked of these three groups on their views regarding arrest, victim responsibility for the abuse, reasons that victims stay, and situations that might justify abuse. In addition, we also wanted to know if attitudes about women's rights contributed to these group's attitudes about woman abuse.

\section{METHOD}

\section{Samples}

In Wisconsin, eleven police departments were asked to provide the police sample; three city and seven small-town departments agreed to participate. An administrator in each department was asked to recruit officers for the study who had recent patrol duty. Of the officers in the small towns, $42(64.6 \%)$ returned the questionnaire. In the city departments, $74(60.7 \%)$ of those who volunteered to participate returned the questionnaire. A total of about $30 \%$ of the officers in all of the departments participated in the study. The sample included 86 patrol officers, with the remainder being of higher rank. Nearly all of the respondents had recent patrol duty. The average number of years of police work was $8.2(\mathrm{SD}=5.7)$. Of the officers, six were women.

The advocate sample was chosen from the five battered women's shelter programs operating in Wisconsin at the time of the study. Of the 62 counselor-advocates at the shelters, 39 (62.9\%) returned questionnaires. The counselor-advocates were salaried or volunteer workers functioning in a variety of roles in direct or indirect service to battered women.

The victim sample was obtained by contacting women at the five shelter programs operating in Wisconsin, except for seven who were 
clients of a family counseling agency. Questionnaires were completed and returned by 52 battered women. Four women refused to participate due to the length of the questionnaire or because they found some of the questions too upsetting.

The demographic information of all three samples is shown in Table 1. Although the samples were not representative of the total populations of police, advocates, and victims in the region, two steps were taken to increase their representativeness: a small incentive fee (\$5) was used with the victim and police samples and samples were chosen from towns and cities of varying size. It was hoped that the incentive fee would attract officers who were not interested in the study out of sympathy for battered women. Having a variety of towns and cities in the study would ensure that respondents had a wider range of demographic characteristics.

\section{Measures}

Except for the Attitudes Toward Women Scale and the MarloweCrowne Social Desirability Scale, all of the measures used in the study were developed by us. Unless otherwise noted, evidence for the reliability and validity of each of the measures and more detailed descriptions of the procedures are presented in a separate report (Saunders, 1980). In the first phase of the study, semistructured interviews were conducted with 16 police officers and 16 battered women regarding their perceptions and experiences with the problem of woman abuse. These interviews were used to refine and develop the research questions further and to generate items for the measures used in the survey. The questionnaire was then pretested using self-administration with 13 officers to determine item readability, vagueness, and response variance. No items were deleted. One item was changed to less extreme wording in order to increase response variance.

Attitudes Toward Women Scale. This is a 25-item measure of opinions about the rights and roles of women on a liberal-traditional continuum (Spence, Helmreich, \& Stapp, 1973). Evidence for the validity and reliability of the scale is given in Spence and Helmreich (1978).

Affective evaluations of police officers and battered women. The semantic differential technique was used to obtain overall affective responses to the stimulus groups "police officers" and "battered women" (Osgood, Tannenbaum, \& Suci, 1957). Respondents rated 15 adjective pairs of opposite meaning on 7-point scales to indicate their 
TABLE 1

Demographic and Background Variables

\begin{tabular}{|c|c|c|c|c|c|c|}
\hline & \multicolumn{2}{|c|}{ Police } & \multicolumn{2}{|c|}{ Victims } & \multicolumn{2}{|c|}{ Advocates } \\
\hline & $n$ & $\%$ & $n$ & $\%$ & $n$ & $\%$ \\
\hline \multicolumn{7}{|l|}{ Marital Status } \\
\hline Single & 18 & 15.7 & 10 & 19.2 & 13 & 33.3 \\
\hline Married & 91 & 79.1 & 12 & 23.1 & 13 & 33.3 \\
\hline Separated & 1 & 0.9 & 24 & 46.2 & 4 & 10.3 \\
\hline Divorced & 5 & 4.3 & 5 & 9.6 & 9 & 23.1 \\
\hline Widowed & 0 & 0.0 & 1 & 1.9 & 0 & 0.0 \\
\hline \multicolumn{7}{|l|}{ Ethnicity } \\
\hline White & 109 & 97.3 & 46 & 88.5 & 37 & 94.9 \\
\hline Black & 0 & 0.0 & 3 & 5.8 & 2 & 5.1 \\
\hline Mexican American & 2 & 1.8 & 2 & 3.8 & 0 & 0.0 \\
\hline Asian & 0 & 0.0 & 1 & 1.9 & 0 & 0.0 \\
\hline \multicolumn{7}{|l|}{ Religion } \\
\hline Protestant & 50 & 43.1 & 29 & 55.8 & 10 & 25.6 \\
\hline Catholic & 63 & 54.8 & 19 & 36.5 & 18 & 46.2 \\
\hline Jewish & 0 & 0.0 & 0 & 0.0 & 9 & 23.1 \\
\hline Other & 2 & 1.7 & 1 & 2.0 & 2 & 5.1 \\
\hline None & 0 & 0.0 & 3 & 5.8 & 0 & 0.0 \\
\hline \multicolumn{7}{|l|}{ Sex } \\
\hline Female & 6 & 5.2 & 52 & 100.0 & 35 & 89.7 \\
\hline Male & 110 & 94.8 & 0 & 0.0 & 4 & 10.3 \\
\hline \multicolumn{7}{|l|}{ College Degree } \\
\hline None & 73 & 63.5 & 47 & 90.4 & 6 & 21.4 \\
\hline$B A, B S$ & 19 & 16.4 & 3 & 5.7 & 15 & 53.6 \\
\hline MA, MS & 0 & 0.0 & 1 & 1.9 & 7 & 25.0 \\
\hline Associate & 22 & 19.0 & 1 & 1.9 & 0 & 0.0 \\
\hline Technician & 1 & 0.9 & 0 & 0.0 & 0 & 0.0 \\
\hline \multicolumn{7}{|l|}{ Years of Schooling } \\
\hline & $\mathrm{M}$ & SD & $\mathrm{M}$ & SD & $\mathrm{M}$ & SD \\
\hline & 14.0 & 1.5 & 12.2 & 2.0 & 15.4 & 2.0 \\
\hline
\end{tabular}

reactions to the stimulus group and show their general attitude toward it. For example, two of the opposing adjective pairs separated by the scale were "dishonest-honest" and "dependable-undependable." The internal reliability coefficients (alpha) for the scales "police officers" and "battered women" were .76 and .78, respectively.

Approval of marital violence scales. Respondents were asked to rate eight different marital violence situations on 7-point scales on 
how "bad," "necessary," or "normal" they viewed them. Examples of situations include the following: "Husband slapping his wife's face if she insults him" and "Husband severely bruising his wife if she was unfaithful." The responses to these situations were factor analyzed (principal axis factoring with varimax rotation); the following four factors were derived: marital violence as (a) bad, (b) normal, (c) justified against insults, and (d) justified against infidelity. Violence toward husbands and wives did not form separate factors. Internal reliability (alpha) coefficients for these scales ranged from .77 to .88 $($ mean $=.85)$.

Beliefs about why victims stay. Respondents were asked to check the three most important reasons out of a list of thirteen reasons that they believed women stayed in abusive relationships (shown in Table 4).

Belief in victim causation of violence. Two items developed for this study were used to measure this attitude variable: "Women who are hit, shoved, or kicked by their husbands or boyfriends usually bring this violence on themselves" and "Women could avoid being hit by their husbands or boyfriends if they knew when to stop talking." Another statement concerning why women might cause their own victimization was also included: "Women experience pain and no pleasure when struck by their husbands or boyfriends." Respondents were asked to indicate their level of agreement or disagreement on 5 -point scales. The mean correlation among these three items was $r=.38($ all $p<.001)$. The alpha coefficient of reliability was .54 .

Marital violence as a crime. Two items were also developed to measure this attitude dimension: "The best way to deal with marital violence is to arrest the offending party" and "When police officers respond to fights between couples they are not really dealing with crime or crime prevention." The correlation between these two items was $r=-.12(p<.05)$. Because of this low correlation, these items were not combined into a single scale.

Social desirability response bias. Self-report measures are often contaminated by social desirability response bias. To detect this bias, an 18-item true-false version of the Marlowe-Crowne Social Desirability Scale was used (Crowne \& Marlowe, 1964). Scores on all but the dichotomous measure "Why victims stay" were adjusted to remove this bias before analyzing the data.

Because this was an exploratory study, post hoc comparisons were made between the samples using Student-Newman-Keuls procedure. Analysis of covariance was used to test the influence of demographic 
variables (gender, age, marital status, education, and income) on sample differences.

\section{RESULTS}

\section{Approval of Violence}

The means on the Marital Violence Approval Scales for the police, victim, and advocate samples are shown in Table 2 . Means are shown both before and after adjusting for the demographic variables using analysis of covariance.

The three samples did not differ significantly on the scale "Marital Violence As Bad," even after adjusting for demographic variables. All of the samples placed marital violence near the end of the scale labeled "bad."

On the scale "Marital Violence As Normal" the police and victims did not differ and were more likely than the advocates to see the violence as normal. After controlling for demographic variables, only the police-advocate difference remained.

None of the samples differed from each other on the scale "Violence Justified Against Insults" on either unadjusted or adjusted means.

On the scale "Violence Justified Against Infidelity" the police differed significantly from victims and advocates. The police were somewhat more inclined to endorse this belief.

\section{Attitudes About Assault Responsibility and Criminality}

Table 3 shows the unadjusted and adjusted means of the three samples' responses to statements about responsibility for woman battering and about the police response.

All three groups tended to agree that battered wives are not responsible for causing their abuse. The police, however, were significantly more likely to attribute responsibility to the wives for their abuse. The difference between the police and advocate groups was removed when controlling for the demographic variables. The demographic variables also seemed to explain the difference between the police and victim samples.

In reaction to the statement that police responding to couples' fights are "not dealing with crime," the victims and police did not 
TABLE 2

Sample Comparisons on the "Approval of Marital Violence" Scales

\begin{tabular}{|c|c|c|c|c|c|}
\hline & $M$ & $S D$ & $p<$ & $M a d j .^{a}$ & $p<<^{b}$ \\
\hline \multicolumn{6}{|c|}{ Marital Violence as Bad } \\
\hline Police & 4.85 & $(1.67)$ & ns & 4.98 & ns \\
\hline Victims & 5.30 & $(0.81)$ & & 4.97 & \\
\hline Police & 4.85 & $(1.67)$ & $\mathrm{ns}$ & 4.84 & ns \\
\hline Advocates & 4.47 & $(0.07)$ & & 4.39 & \\
\hline Victims & 5.30 & $(0.81)$ & ns & 5.06 & ns \\
\hline Advocates & 4.47 & $(0.07)$ & & 4.76 & \\
\hline \multicolumn{6}{|c|}{ Marital Violence as Normal } \\
\hline Police & 2.29 & $(1.13)$ & ns & 2.14 & ns \\
\hline Victims & 2.19 & $(1.63)$ & & 1.33 & \\
\hline Police & 2.29 & $(1.13)$ & .001 & 2.40 & .006 \\
\hline Advocates & 1.44 & $(1.06)$ & & 1.10 & \\
\hline Victim & 2.19 & $(1.63)$ & .006 & 1.97 & ns \\
\hline Advocates & 1.44 & $(1.06)$ & & 1.73 & \\
\hline \multicolumn{6}{|c|}{ Violence Justified Against Insults } \\
\hline Police & 1.41 & $(0.67)$ & $\mathrm{ns}$ & 1.58 & $\mathrm{~ns}$ \\
\hline Victims & 1.37 & $(0.97)$ & & .97 & \\
\hline Police & 1.41 & $(0.67)$ & ns & 1.38 & ns \\
\hline Advocates & 1.05 & $(0.28)$ & & 1.18 & \\
\hline Victims & 1.37 & $(0.97)$ & $\mathrm{ns}$ & 1.31 & ns \\
\hline Advocates & 1.05 & $(0.28)$ & & 1.10 & \\
\hline \multicolumn{6}{|c|}{ Violence Justified Against Infidelity } \\
\hline Police & 2.08 & $(1.46)$ & .03 & 2.14 & ns \\
\hline Victims & 1.46 & $(1.10)$ & & 1.33 & \\
\hline Police & 2.08 & $(1.46)$ & .0001 & 2.03 & ns \\
\hline Advocates & 1.08 & $(0.35)$ & & 1.23 & \\
\hline Victim & 1.46 & $(1.10)$ & $\mathrm{ns}$ & 1.36 & ns \\
\hline Advocates & 1.07 & $(0.35)$ & & 1.20 & \\
\hline
\end{tabular}

a. Means are adjusted for demographic variables using ANCOVA.

b. Significance levels for adjusted means and set of demographic variables.

differ but both of these groups differed from the advocates. The police and victims were more likely to agree with this statement. The difference between the police and advocate samples again did not exist after controlling for demographic variables. 


\section{TABLE 3}

\section{Sample Comparisons on Statements of Abuse Responsibility and Criminality}

\begin{tabular}{|c|c|c|c|c|c|}
\hline & $M$ & $S D$ & $p<$ & $M a d j{ }^{\mathrm{a}}$ & $p<<^{b}$ \\
\hline \multicolumn{6}{|c|}{ Battered wives responsible for abuse } \\
\hline $\begin{array}{l}\text { Police } \\
\text { Victims }\end{array}$ & $\begin{array}{l}5.94 \\
4.31\end{array}$ & $\begin{array}{l}(2.77) \\
(3.91)\end{array}$ & .05 & $\begin{array}{l}5.25 \\
6.07\end{array}$ & ns \\
\hline $\begin{array}{l}\text { Police } \\
\text { Advocates }\end{array}$ & $\begin{array}{l}5.94 \\
2.97\end{array}$ & $\begin{array}{l}(2.77) \\
(4.08)\end{array}$ & .05 & $\begin{array}{l}5.38 \\
4.87\end{array}$ & ns \\
\hline $\begin{array}{l}\text { Victims } \\
\text { Advocates }\end{array}$ & $\begin{array}{l}4.31 \\
2.97\end{array}$ & $\begin{array}{l}(3.91) \\
(4.08)\end{array}$ & ns & $\begin{array}{l}4.59 \\
2.69\end{array}$ & ns \\
\hline \multicolumn{5}{|c|}{$\begin{array}{l}\text { When police officers respond to fights between couples } \\
\text { they are not really dealing with crime or crime prevention }\end{array}$} & \\
\hline $\begin{array}{l}\text { Police } \\
\text { Victims }\end{array}$ & $\begin{array}{l}3.67 \\
3.47\end{array}$ & $\begin{array}{l}(1.27) \\
(1.56)\end{array}$ & ns & $\begin{array}{l}3.78 \\
3.20\end{array}$ & ns \\
\hline $\begin{array}{l}\text { Police } \\
\text { Advocates }\end{array}$ & $\begin{array}{l}3.67 \\
4.73\end{array}$ & $\begin{array}{l}(1.27) \\
(0.97)\end{array}$ & .05 & $\begin{array}{l}3.71 \\
4.60\end{array}$ & ns \\
\hline $\begin{array}{l}\text { Victims } \\
\text { Advocates }\end{array}$ & $\begin{array}{l}3.47 \\
4.73\end{array}$ & $\begin{array}{l}(1.56) \\
(0.97)\end{array}$ & .05 & $\begin{array}{l}3.51 \\
4.68\end{array}$ & .01 \\
\hline \multicolumn{6}{|c|}{$\begin{array}{l}\text { The best way to deal with marital violence } \\
\text { is to arrest the offending party }\end{array}$} \\
\hline $\begin{array}{l}\text { Police } \\
\text { Victims }\end{array}$ & $\begin{array}{l}4.25 \\
2.43\end{array}$ & $\begin{array}{l}(0.89) \\
(1.30)\end{array}$ & .05 & $\begin{array}{l}4.28 \\
2.37\end{array}$ & .001 \\
\hline $\begin{array}{l}\text { Police } \\
\text { Advocates }\end{array}$ & $\begin{array}{l}4.25 \\
3.00\end{array}$ & $\begin{array}{l}(0.89) \\
(1.28)\end{array}$ & .05 & $\begin{array}{l}4.52 \\
2.12\end{array}$ & .001 \\
\hline $\begin{array}{l}\text { Victims } \\
\text { Advocates }\end{array}$ & $\begin{array}{l}2.43 \\
3.00\end{array}$ & $\begin{array}{l}(1.30) \\
(1.28)\end{array}$ & .05 & $\begin{array}{l}2.38 \\
3.06\end{array}$ & ns \\
\hline
\end{tabular}

a. Means are adjusted for demographic variables using ANCOVA.

b. Significance levels for adjusted means and set of demographic variables.

Reactions to the statement that arrest is the best way to deal with the problem were the most divergent among the samples. The victims most strongly agreed with this statement, followed by the advocates, and then by the police. Converting the data to percentages, $63 \%$ of the victims agreed (mildly or strongly) that arrest was the best solution, compared with $38 \%$ of the advocates and only $4 \%$ of the police.

A separate question asked the battered women if they thought men who batter should be punished. Of the 39 women answering this question, 36 said "yes." However, about half of these women wanted 
the punishment to include inpatient or outpatient mental health services.

\section{Beliefs About Why Victims Stay}

Table 4 shows the data on the three samples' perspectives on why women remain in abusive relationships. The advocates saw economic dependence, "no place else to go," and "lacks self-confidence" as major explanations. Between $50 \%$ and $90 \%$ of the advocates gave these as major reasons. The victims also emphasized a lack of selfconfidence (44\%) and "no place to go" (48\%) as reasons, but named additional psychological reasons: loving the man (42\%), believing that the children need their father (23\%), hoping the marriage will improve (31\%), and feeling sorry for the man (13\%). The victims and advocates differed significantly (using tables of percentage differences; Warwick \& Lininger, 1975) on three of the items: love for man, economic dependence, and no place to go. The victims significantly differed from the police on two of the items: economic dependence and "feels sorry for her husband." Unlike the attitudes about victim causation of violence, the police had perceptions closer to the victims than the advocates did. The total police-victim difference in percentage points was 97.9 compared with 177.2 for the advocate-victim difference.

\section{Affective Evaluations of Victims and Police}

Victims had significantly more positive evaluations of battered women than police officers on the semantic differential technique. However, this difference did not exist after controlling for the demographic variable of income. There were no significant differences between advocates and the other two groups.

The stimulus "police officers" received significantly more positive ratings from officers than either victims or advocates. Furthermore, victims gave significantly more positive ratings than advocates. The difference between police and victims was not maintained after controlling for demographic variables.

\section{Correlates of Attitudes About Women}

All of the continuous variables compared across samples were also correlated with the Attitudes Toward Women Scale within each sample. In each of the samples there was a significant, positive relationship between approval of marital violence (combining the 
TABLE 4

Percentage of Respondents Giving Explanations for Why Women Stay in Abusive Relationships

\begin{tabular}{|c|c|c|c|c|}
\hline Explanation & Police & Victim & Advocate & \\
\hline $\begin{array}{l}\text { Economically dependent } \\
\text { on the man }\end{array}$ & 69.9 & 34.6 & 89.5 & $V<P<A$ \\
\hline No place else to go & 44.4 & 48.1 & 81.6 & $\mathrm{PV}<\mathrm{A}$ \\
\hline $\begin{array}{l}\text { Fear of greater violence } \\
\text { from him }\end{array}$ & 35.6 & 26.9 & 23.7 & \\
\hline Love for the man & 33.9 & 42.0 & 15.8 & $V>A$ \\
\hline Lacks self-confidence & 31.3 & 44.2 & 50.0 & $P<A$ \\
\hline $\begin{array}{l}\text { Hope that marriage will } \\
\text { improve }\end{array}$ & 28.7 & 30.8 & 18.4 & \\
\hline $\begin{array}{l}\text { Believe the children need } \\
\text { their father }\end{array}$ & 24.3 & 23.1 & 13.2 & \\
\hline Stigma of divorce & 13.0 & 9.6 & 0.0 & $P>A$ \\
\hline $\begin{array}{l}\text { Desire to stay in role } \\
\text { of wife }\end{array}$ & 4.4 & 9.6 & 2.6 & \\
\hline The violence is not severe & 3.5 & 1.9 & 0.0 & \\
\hline Enjoys pain & 3.5 & 0.0 & 0.0 & \\
\hline $\begin{array}{l}\text { Enjoys intense emotional } \\
\text { experience }\end{array}$ & 2.6 & 1.9 & 0.0 & \\
\hline Feels sorry for husband & 1.7 & 13.5 & 2.6 & $\mathrm{P}<\mathrm{V}$ \\
\hline
\end{tabular}

NOTE: Percentages add to more than $100 \%$ because respondents were asked to give the three best explanations for why women stay in abusive relationships. $P=$ police; $V=$ victims; $A=$ advocates. $\angle=$ significant difference in direction shown $(p<.05)$.

four scales) and traditional views of women's roles (police, $r=.43, p<$ .001 ; victims, $r=.21, p<.05$; advocates, $r=.58, p<.001)$. For the police sample only, endorsement of traditional roles for women was significantly associated with views that victims cause the violence $(r=.41$, $\mathrm{p}<.001)$ and that arrests should not be made $(\mathrm{r}=.33, \mathrm{p}<.001)$.

\section{DISCUSSION}

The three samples did not differ very much in their degree of acceptance of marital violence in general or as a response to verbal aggression. Officers, however, were more approving of violence as a 
reaction to marital infidelity. This difference may be accounted for by gender differences among the samples. The male officers are likely to hold more traditional views of women as property and may think women need to be punished if unfaithful.

Officers and victims viewed marital violence as somewhat more normal than the advocates, perhaps because advocates had less direct experience with abusive situations or took the word "normal" to mean acceptable rather than prevalent. If the advocates equated "normal" with acceptance of violence, then their response may be the result of a stronger feminist position.

Although the officers generally agreed that battered women do not cause their abuse or enjoy it, they did not agree as much with these beliefs as the victims or advocates. Again, gender differences may explain the differences in attitudes.

Using the Attitudes Toward Women Scale, there was evidence that the belief among officers that victims are responsible for causing their abuse stems from traditional views of women's roles. These results parallel those of Feild's (1978) study of attitudes toward rape that found that for samples of police officers and citizens, traditional views of women were associated with holding rape victims accountable for their rapes. As mentioned in the introduction, there is some evidence that attitudes determine the extent of officer action, with stronger sexist attitudes and greater general approval of marital violence associated with a lessened tendency to arrest, counsel, or refer in domestic violence cases (Saunders, 1980).

Most officers viewed the abuse as criminal but, in contrast to victims, very few thought that arrest was the best solution. Such divergent viewpoints may explain the dissatisfaction many victims feel with the police response. A difference between victim wishes and officer behavior has been found in other studies (Oppenlander, 1982; Pagelow, 1981). A major difference between victim and officer perspectives seems to center around differing goals for arrest. Victims often want arrest for immediate protection (Ford, 1983; Reed et al., 1983 ) and to force the abuser into treatment, results that were found here and by Bowker (1983). They do not usually want arrest used as a means to put the abuser in jail or prison. Officers, on the other hand, often feel they have wasted their time if arrest does not lead to prosecution and jail time (Reed et al., 1983). Both victims and officers may look more favorably upon arrest if presented with evidence that men who batter most severely are least likely to seek help voluntarily (Brisson, 1982; Hanneke \& Shields, 1981). 
The police officers seemed to have a greater understanding of victims' emotional ties to the relationship than the advocates for battered women. This understanding may occur because officers, unlike most advocates, have repeated contact with some families over a period of months or years and because advocates may be more inclined to believe that it is solely a lack of material options that prevents battered women from leaving. Davis (1984) found that shelter workers were much more likely than officers to believe that a lack of resources for victims helped perpetuate the abuse. It is also possible, however, that the victims were overemphasizing the psychological factors in their explanations for why victims stay because they had less control over the external, material factors. The officers' attributions for why victims stay may be a cause of their frustrations because they see the emotional entrapment of the women, which means longer-term, more complex solutions than shelter and economic aid.

The findings of this study provide some implications for training. Because traditional views of women by officers are associated with victim-blaming and inaction, those who train officers should continue to use and possibly expand their use of consciousness-raising material about women and women as victims. Training material can be inspected for sexist and other forms of bias. Several police training guides are available on the topic of battered women (e.g., IACP, 1977; Loving, 1981; Pennsylvania Coalition, 1981) and can be supplemented with films and presentations by battered women describing their experiences. Of course, the implementation of policies based on sound outcome research (e.g., Sherman \& Berke, 1984) may produce more effective results than changing attitudes. However, this is a question deserving study and negative attitudes may explain why some officers do not follow the new proarrest policies.

The finding that advocates, compared with victims, had less favorable impressions of officers implies the need for improving policeadvocate relationships. Stevenson (1980) has designed and conducted joint problem-solving workshops with police officers, advocates for battered women, mental health workers, and other professionals with the aim of improving relationships among these groups. These workshops were especially useful in building informal networks of referral and collaboration. There is evidence that such networks dramatically increase the rates of referral between advocacy groups and the criminal justice system (Gamache, Edleson, \& Schock, in press; Hanewicz, Cassidy-Riske, Fransway, \& O’Neill, 1982).

All of the above findings and recommendations need to be taken cautiously due to the limitations of the study. The samples were 
relatively small and nonrepresentative and attempts to improve the representativeness of the samples may not have been successful. Because the victims were seeking help, they were more likely to be severely abused (Washburne \& Frieze, 1981). Their expectations of the police may differ from other battered women. Because of the small number of female police officers, their responses could not be analyzed separately. As views about women's roles were important variables in this study, a study that compares male and female officers' views is recommended. Finally, the three-item scale measuring the belief in victim causation of abuse had very low internal reliability. A measure of attitudes about woman abuse, including attributions of causation, has been developed since this study and it shows much higher coefficients of reliability (Saunders, Lynch, \& Grayson, 1985).

Taking the above limitations into account, this study suggests reasons for differing views between victims and the police on the police role in domestic violence cases and reveals that sexist attitudes of the police are related to victim-blaming. It also indicates some sources of strain between police and advocate groups. The findings provide implications for improving police-advocate relationships and for the training of police officers and advocates.

\section{REFERENCES}

Bannon, J. (1975). Law enforcement problems with intra-family violence. Speech given to Annual Conference of the American Bar Association, August 12, Montreal, Canada.

Bard, M., \& Connolly, H. (1978). The police and family violence: Policy and practice. In Battered women: Issues of public policy (pp. 304-326). Washington, DC: U.S. Civil Rights Commission.

Black, D. (1982). The manners and customs of the police. New York: Academic.

Borkowski, M., Murch, M., \& Walker, V. (1983). Marital violence: The community response. London: Tavistock.

Borofsky, G., Stollak, G., \& Messe, L. (1971). Bystander reactions to physical assault: Sex differences in socially responsible behavior. Journal of Experimental Social Psychology, 7, 313-318.

Bowker, L. H. (1983). Beating wife-beating. Lexington, MA: Lexington Books.

Brisson, N. (1982). Helping men who batter women. Public Welfare, pp. 29-34.

Carlson, B. E. (1977, November). Battered women and their assailants. Social Work, 22, 455-460.

Crowne, D. P., \& Marlowe, D. (1964). The approval motive: Studies in evaluative dependence. New York: John Wiley.

Davis, L. V. (1984, May/June). Beliefs of service providers about abused women and abusing men. Social Work, pp. 243-250. 
Feild, H. S. (1978). Attitudes toward rape: A comparative analysis of police, rapists, crisis counselors, and citizens. Journal of Personality and Social Psychology, 36(2), 156-179.

Field, M. H., \& Field, H. F. (1973). Marital violence and the criminal process: Neither justice nor peace. Social Service Review, 43 (2), 221-240.

Fields, M. (1978). Wife beating: Government intervention policies and practices. In Battered women: Issues of public policy (pp. 228-287). Washington, DC: U.S. Civil Rights Commission.

Fojtik, K. M. (1977/1978). The NOW domestic violence project. Victimology: An International Journal, 2 (3/4), 653-657.

Ford, D. A. (1983). Wife battery and criminal justice: A study of victim decisionmaking. Family Relations, 32, 463-475.

Gamache, D. J., Edleson, J. L., \& Schock, M. D. (in press). Coordinated police, judicial and social service response to women battering: A multiple-baseline evaluation across three communities. Beverly Hills, CA: Sage.

Gaquin, D. (1977). Spouse abuse: Data from the National Crime Survey. Victimology, 2, 632-643.

Gregory, M. (1976). Battered wives. In M. Borland (Ed.), Violence in the family. Manchester, England: Manchester University Press.

Hanewicz, W. B., Cassidy-Riske, C., Fransway, L. M., \& O’Neill, M. W. (1982). Improving the linkages between domestic violence referral agencies and the police: A research note. Journal of Criminal Justice, 10, 493-503.

Hanneke, C. R., \&c Sheilds, N. M. (1981, July). Patterns of family and nonfamily violence: An approach to the study of violent husbands. Unpublished paper presented at the National Conference for Family Violence Researchers, Durham, NH.

International Association of Chiefs of Police (IACP). (1977). Training Key \#245 and \#246. In M. Roy(Ed.), Battered women: A psychological study of domestic violence (pp. 144-163). New York: Van Nostrand.

Lerman, L. (1981). Prosecution of spouse abuse. Washington, DC: Center for Women's Policy Studies.

Libow, J. A., Raskin, P. A., \& Caust, L. (1982). Feminist and fan y systems: Are they irreconcilable? American Journal of Family Therapy, 10, 3-1\%.

Loving, N. (1981). Spouse abuse: A curriculum guide for police trainers. Washington, DC: Police Executive Research Forum.

Martin, D. (1976). Battered wives. San Francisco: Glide.

Oppenlander, N. (1982). Coping or copping out. Criminology, 20 (3/4), 449-465.

Osgood, C. E., Tannenbaum, P. H., \& Suci, G. (1957). The measurement of meaning. Urbana: University of Illinois Press.

Pagelow, M. D. (1981). Woman-battering: Victims and their experiences. Beverly Hills, CA: Sage.

Pennsylvania Coalition Against Domestic Violence. (1981). Domestic violence: A guide for police response. Unpublished manuscript, Pennsylvania Coalition Against Domestic Violence, Harrisburg, PA.

Price, J., \& Armstrong, J. (1978). Battered wives: A controlled study of predispositions. Australian and New Zealand Journal of Psychiatry, 12 (1), 43-48.

Reed, D., Fischer, S., Kantor, G. K., \& Karales, K. (1983). All they can do: Police response to battered women's complaints. Chicago: Chicago Law Enforcement Study Group. 
Roy, M. (1977). A current survey of 150 cases. In M. Roy (Ed.), Battered women: A psychosociological study of domestic violence (pp. 25-44). New York: Van Nostrand Reinhold.

Saunders, D. G. (1980). The police response to battered women: Predictors of officers' use of arrest, counseling and minimal action. Dissertation Abstracts International, 40, 6446A. (University Microfilms No. 80-08840).

Saunders, D. G., \& Size, P. B. (1980). Marital violence and the police: A survey of police officers, victims and victim advocates. Unpublished research report to the Wisconsin Council on Criminal Justice, Madison, Wisconsin.

Saunders, D. G., Lynch, A. E., \& Grayson, M. (1985). The inventory of beliefs about wife-beating: The construction and initial validation of a measure of beliefs and attitudes. Manuscript submitted for publication.

Sherman, L. W., \& Berke, R. A. (1984). Deterrent effects of arrest on domestic violence. American Sociological Review, 49 (2), 261-271.

Shotland, R. L., \& Straw, M. K. (1976). Bystander response to an assault: When a man attacks a woman. Journal of Personality and Social Psychology, 32, 990-999.

Smith, B. E. (1983). Non-stranger violence: The criminal courts' response. Washington, DC: National Institute of Justice.

Spence, J. T., \& Helmreich, R. L. (1978). Masculinity and femininity: Their psychological dimensions, correlates, and antecedents. Austin: University of Texas.

Spence, J. T., Helmreich, R., \& Stapp, J. (1973). A short version of the Attitudes Toward Women Scale (AWS). Bulletin of the Psychonomic Society, 2 (4), 219-220.

Star, B., Clark, C., Goetz, K., \& O'Malia, L. (1979). Psychosocial aspects of wife battering. Social Casework, 60, 479-487.

Stevenson, W. J. (1980). Police-social service project: Final report to the Wisconsin council on criminal justice. Madison: Wisconsin Center for Public Policy.

Straus, M. A., Gelles, R. J., \& Steinmetz, S. K. (1980). Behind closed doors: Violence in the American family. New York: Doubleday.

Truninger, E. (1971). Marital violence: The legal solutions. Hastings Law Journal, 23, 259-276.

U.S. Commission on Civil Rights. (1982). Under the rule of thumb: battered women and the administration of justice. Washington, DC: Author.

Warwick, D. P., \& Lininger, C. A. (1975). The sample survey. New York: McGraw-Hill.

Washburne, C., \& Frieze, I. H. (1981). Methodological issues in studying battered women. Paper presented at the National Conference for Family Violence Researchers, University of New Hampshire.

Woods, L. (1981). Litigation on behalf of battered women. Women's Rights Law Reporter, 7(1), 39-46.

Wylie, P., Basinger, L., Heinecke, C., \& Rueckert, J. (1976). An approach to evaluating a police program of family crisis intervention in six demonstration cities. Alexandria, VA: Human Resources Organization.

Daniel G. Saunders is a Postdoctoral Research Fellow at the Department of Psychiatry, University of Wisconsin Schoöl of Medicine, and Program Evaluator, Program to Prevent Woman Abuse, Family Service, Madison, Wisconsin. He has helped develop 
programs for battered women and men who batter and written several articles on working with men who batter. For one year he was a postdoctoral research fellow at the Family Violence Research Program at the University of New Hampshire.

Patricia B. Size, R.N., M.S., is a Nursing Instructor at the Mendota Mental Health Institute, Madison, Wisconsin. She has helped develop services for battered women and has presented workshops on detecting and preventing domestic violence. Her master's thesis was titled "An Exploratory Study of Wife Assault in Madison, Wisconsin." 